http://dx.doi.org/10.11646/phytotaxa.277.1.1

\title{
Multilocus phylogeny reveals Gibsmithia hawaiiensis (Dumontiaceae, Rhodophyta) to be a species complex from the Indo-Pacific, with the proposal of $G$. eilatensis $s p$. nov.
}

\author{
DANIELA GABRIEL ${ }^{1,2,}$, , STEFANO G.A. DRAISMA ${ }^{3}$, THOMAS SAUVAGE ${ }^{2}$, WILLIAM E. SCHMIDT ${ }^{2}$, TOM \\ SCHILS $^{4}$, PHAIK-EEM LIM ${ }^{5}$, D. JAMES HARRIS ${ }^{1} \&$ SUZANNE FREDERICQ $^{2}$ \\ ${ }^{I}$ CIBIO, Centro de Investigação em Biodiversidade e Recursos Genéticos, InBIO Laboratório Associado, Pólo dos Açores - Departa- \\ mento de Biologia da Universidade dos Açores, R. Mãe de Deus 13A, 9501-801 Ponta Delgada, Portugal \\ ${ }^{2}$ Department of Biology, University of Louisiana at Lafayette, Lafayette, LA 70504-3602, USA \\ ${ }^{3}$ Center of Excellence for Biodiversity of Peninsular Thailand, Faculty of Science, Prince of Songkla University, Hat Yai, Songkhla \\ 90112, Thailand \\ ${ }^{4}$ University of Guam Marine Laboratory, UOG Station, Mangilao, GU 96923, Guam, USA \\ ${ }^{5}$ Institute of Ocean and Earth Sciences, University of Malaya, Kuala Lumpur 50603, Malaysia \\ *danielalgabriel@gmail.com.
}

\begin{abstract}
Gibsmithia hawaiiensis is a peculiar red alga characterized by furry gelatinous lobes arising from a cartilaginous stalk. The species has been recorded from tropical reef systems throughout the Indo-Pacific. A multilocus phylogeny (UPA, $r b c \mathrm{~L}$, COI$5 \mathrm{P}$ ) of 36 specimens collected throughout the species distribution range, showed high genetic diversity at species level. Two major groups were identified, each consisting of multiple lineages. Genetic variability was low in the Hawaiian Islands and the northern Red Sea and high in the Western Indian Ocean and the Coral Triangle, where lineages overlap in distribution. Genetic distances suggest that $G$. hawaiiensis represents a complex of five cryptic species, with no difference observed in the external morphology corresponding to separate lineages. Anatomical and reproductive differences were observed at the microscopic level for the lineage from the Red Sea, which is here described as G. eilatensis sp. nov. The geographic range of the species complex is here expanded to include Madagascar, the Red Sea and the Indo-Malay region, and the generitype seems endemic to the Hawaiian Islands. Algal diversity on coral reef systems is discussed from a conservation perspective using G. hawaiiensis as an example.
\end{abstract}

Keywords: Cryptic species, DNA barcoding, Dudresnaya, Gigartinales, systematics

\section{Introduction}

The genus Gibsmithia (Dumontiaceae, Gigartinales) was erected in 1963 (Doty) for a marine red alga characterized by an ephemeral cluster of gelatinous lobes borne from a perennial cartilaginous stalk. There are currently four species within the genus, G. hawaiiensis Doty 1963:458 (type of the genus), G. dotyi Kraft \& R.W. Ricker 1984:433, G. larkumii Kraft 1986:439, and G. womersleyi Kraft \& Ricker ex Kraft 1986:441, each with well-defined diagnostic features based on their external morphology (Kraft 1986). G. hawaiiensis stands out from its congeners by having cortical filaments that extend beyond the surface of the gelatinous lobes, giving the plant an overall furry appearance (Fig. 1). Nevertheless, the above four species of Gibsmithia share a female reproductive system consisting of separate carpogonial- and auxiliary-cell filaments, and isomorphic tetrasporophytes (Kraft 1986).

Gibsmithia is widespread throughout the Indo-Pacific, with G. hawaiiensis presenting the largest distribution range (Fig. 2), occurring on coral reefs from South Africa to French Polynesia and the Hawaiian Islands (Guiry \& Guiry 2016). Recent records from scattered localities suggest that the species is more common than once thought (Abbott 1999) and might have been overlooked by collectors because of (1) its ephemeral occurrence in the subtidal, (2) low population abundances, and (3) its resemblance to soft corals. 


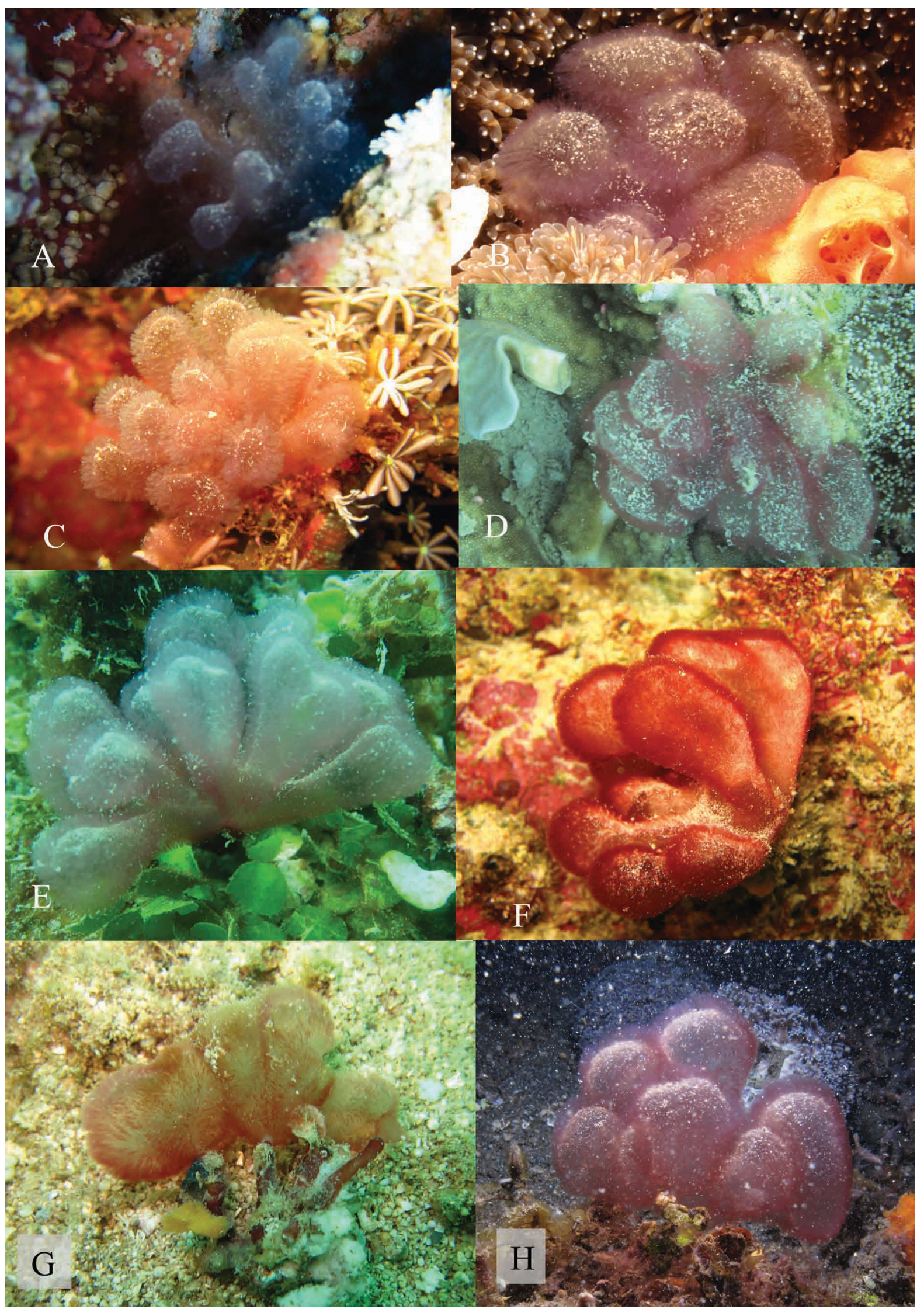

FIGURE 1. In situ habits of Gibsmithia hawaiiensis complex. A) DG234, Eilat, Israel. B) SGAD0509563, Kepulauan Seribu, Indonesia. C) SGAD0911460, Ternate, Indonesia. D) TIG001, Pulau Tiga, Malaysia. E) SGAD1205119, Johor, Malaysia. F) SGAD0712185, Raja Ampat, Indonesia. G) SGAD1206005, Labuan, Malaysia. Four individuals, each comprising one stipe and one to a few lobes. H) LEM03, Bitung, Indonesia. Scale bar 1 cm. Photo credits: A) T. Sauvage; B) A. Gittenberger; C, E-G) S.G.A. Draisma; D) M.A.S. Hussein; H) B.T. Reijnen. 


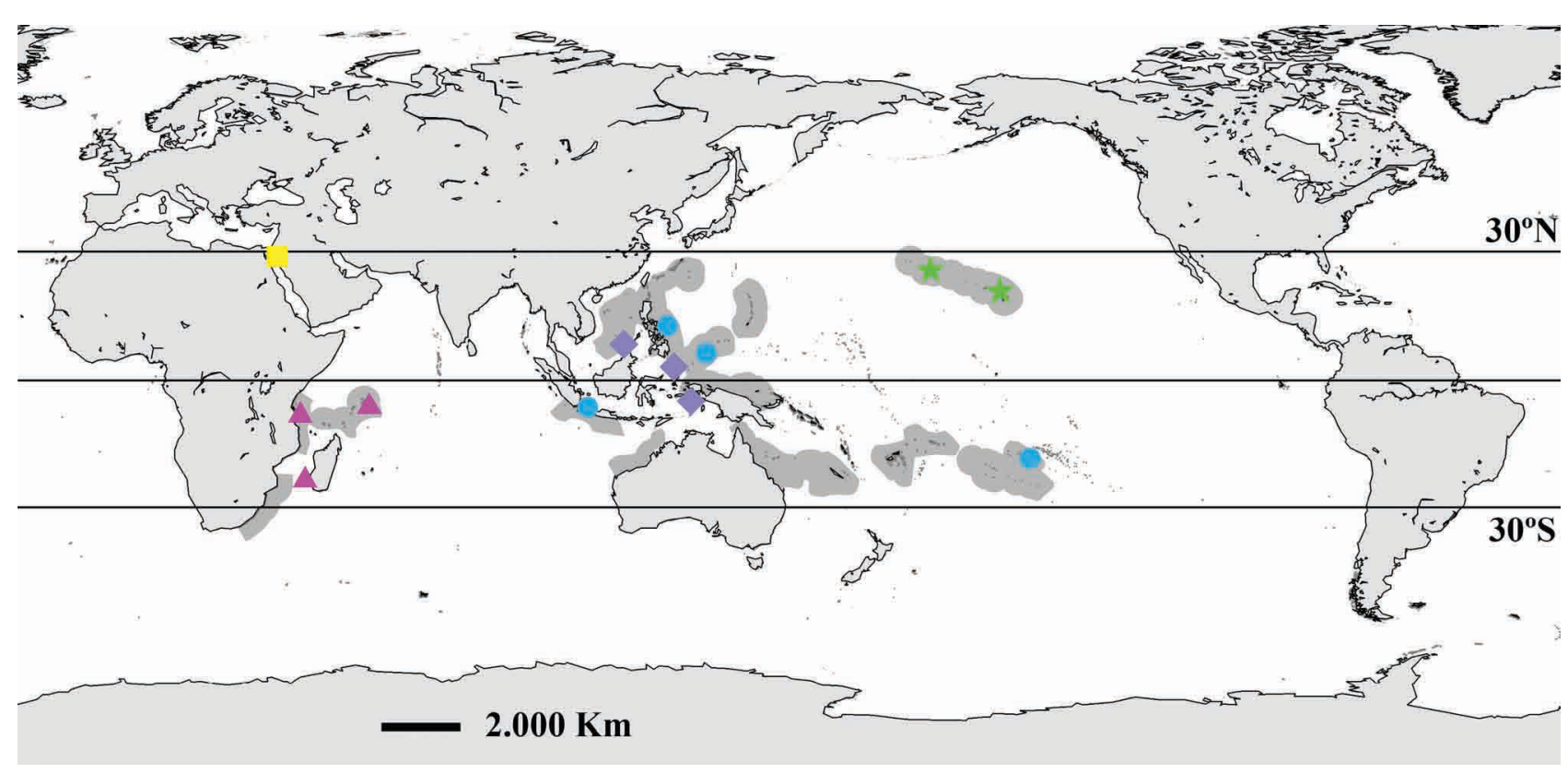

FIGURE 2. Reported distribution of Gibsmithia hawaiiensis prior to this study (grey shade), based on records listed in AlgaeBase (Guiry \& Guiry 2016): Africa: South Africa, Tanzania; Indian Ocean Islands: Seychelles; Asia: China, Japan, Taiwan; South-east Asia: Indonesia, Philippines, Vietnam; Australia and New Zealand: Australia, Coral Sea Islands Territory, Papua New Guinea, Queensland, Western Australia; Pacific Islands: Central Polynesia, Federated States of Micronesia, Fiji, French Polynesia, Guam, Hawaiian Islands, Mariana Islands, Northern Hawaiian Islands, Republic of Palau. Collection sites are marked with shapes corresponding to the different lineages from Fig. 3.

The disjunct distribution pattern of the species, its short-lived reproductive structures (Huisman et al. 2007), and the low survival rate of the soft and gelatinous thallus during long periods of drift (Millar and Kraft 1984) suggest that the species may be a poor disperser. Such a lack of connectivity between populations, however, has not been reflected in external morphological differences between samples from distant geographical localities.

Recent genetic studies have demonstrated the high degree of cryptic diversity among red algae (e.g., Freshwater $e t$ al. 2010; Payo et al. 2013), particularly in groups with simple morphologies like the Dumontiaceae (Saunders 2008). Phylogenetic assessments of other members of the family that included Gibsmithia hawaiiensis and G. dotyi suggested the monophyly of the genus (Sherwood et al. 2010; Clarkston and Saunders 2012). The present study is the first to focus on assessing the molecular diversity within the genus, with extensive sampling of its most common species throughout the Indo-Pacific, i.e. G. hawaiiensis.

\section{Materials and Methods}

Seventeen specimens were collected by snorkeling or SCUBA diving during collection trips to Israel, Indonesia, Malaysia and Hawaii, from 2005 to 2011. Samples were preserved in a 5\% formalin-seawater solution, pressed or airdried on herbarium sheets, with a subsample dried in silica gel or kept in $96 \%$ ethanol. Twelve Hawaiian specimens were obtained from the personal collections of Dr. I.A. Abbott, and ten additional samples were obtained from herbaria (Table 1). Identification of specimens used was based on the identification key provided in Kraft (1986).

Morphological analysis. Permanent slides were prepared from squashes using 1\% aniline blue (Tsuda \& Abbott 1985), mounted in 50\% corn syrup-water with the addition of a few drops of phenol. Anatomical observations were done using an Olympus BX60 light microscope (Tokyo, Japan) and cells were measured (presented as length $\times$ width) using an eyepiece with scales coupled to the microscope. Pictures were taken with a Canon EOS Rebel T2i digital camera (Tokyo, Japan) connected to the microscope, using the software EOS Utility 2.8.1 (Tokyo, Japan). All images were edited in Photoshop 6.0.1 (San Jose, USA). 


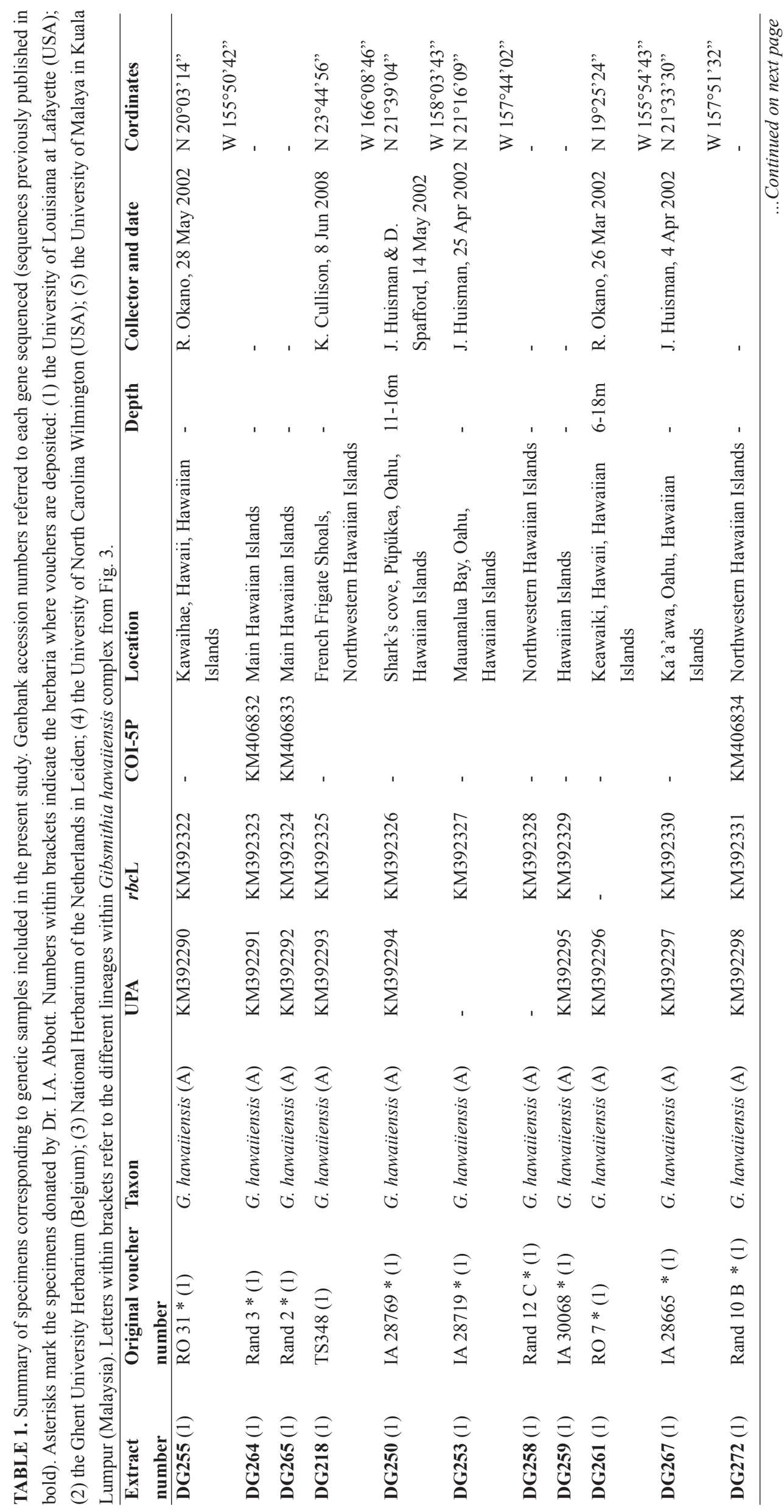




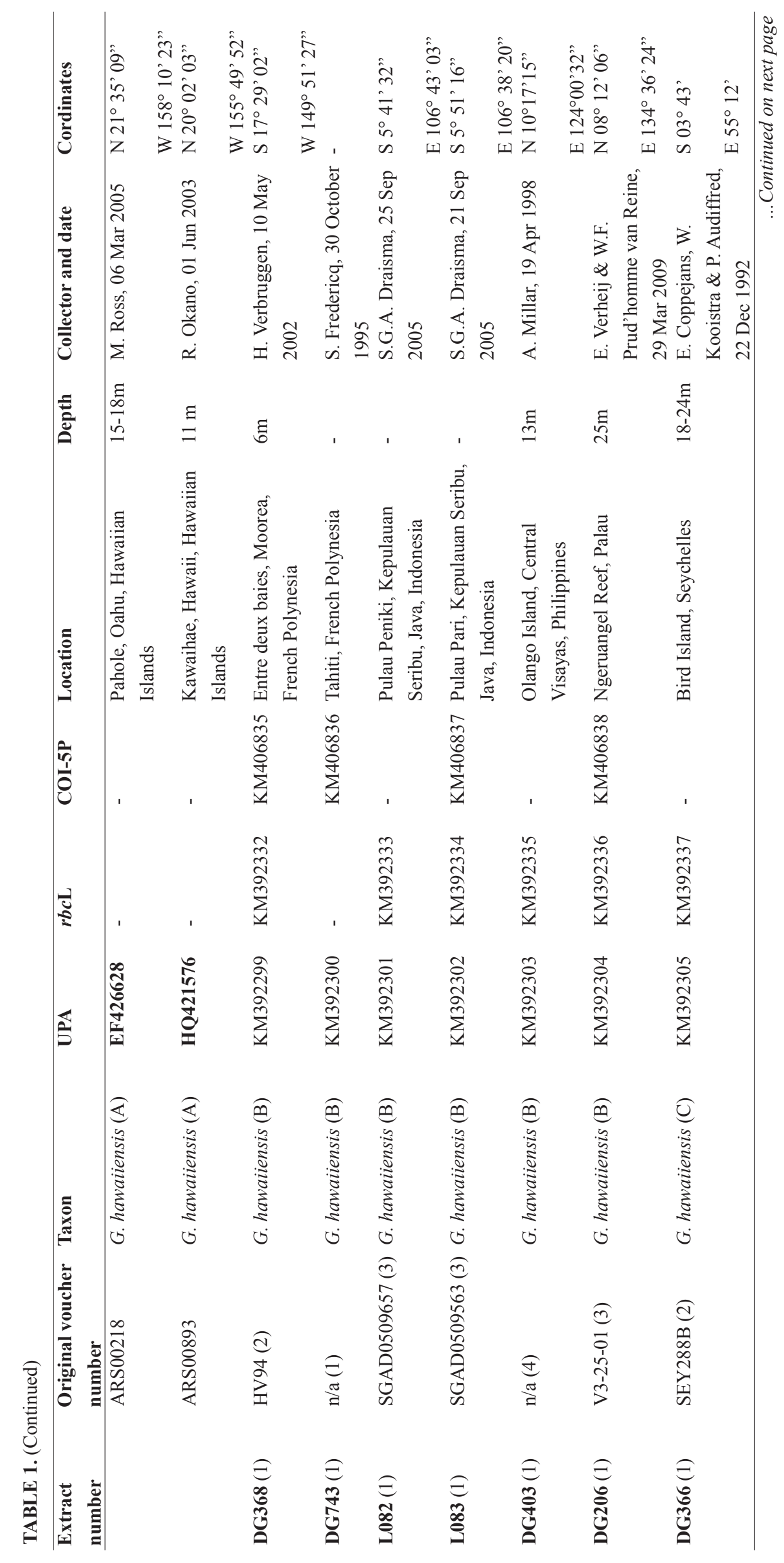




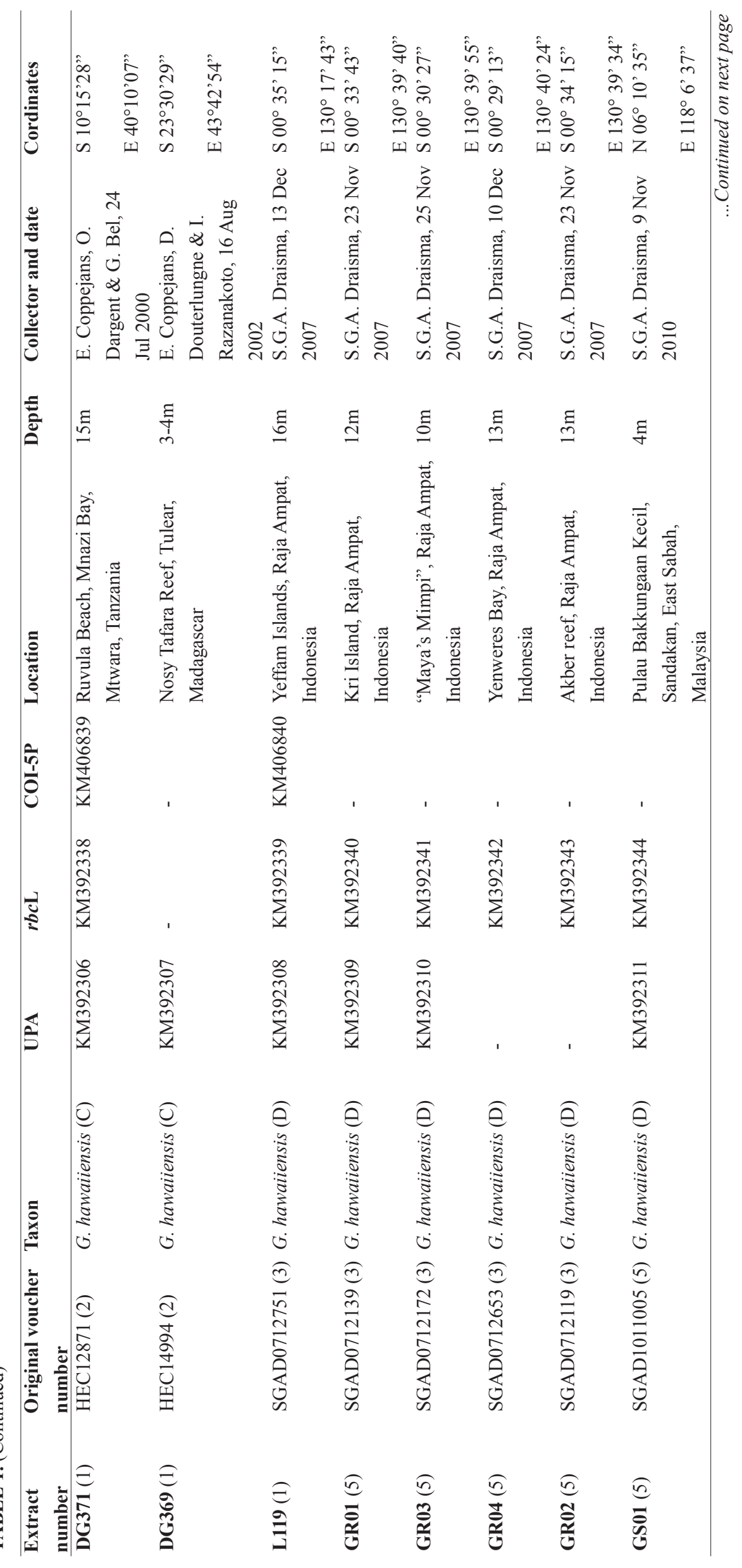




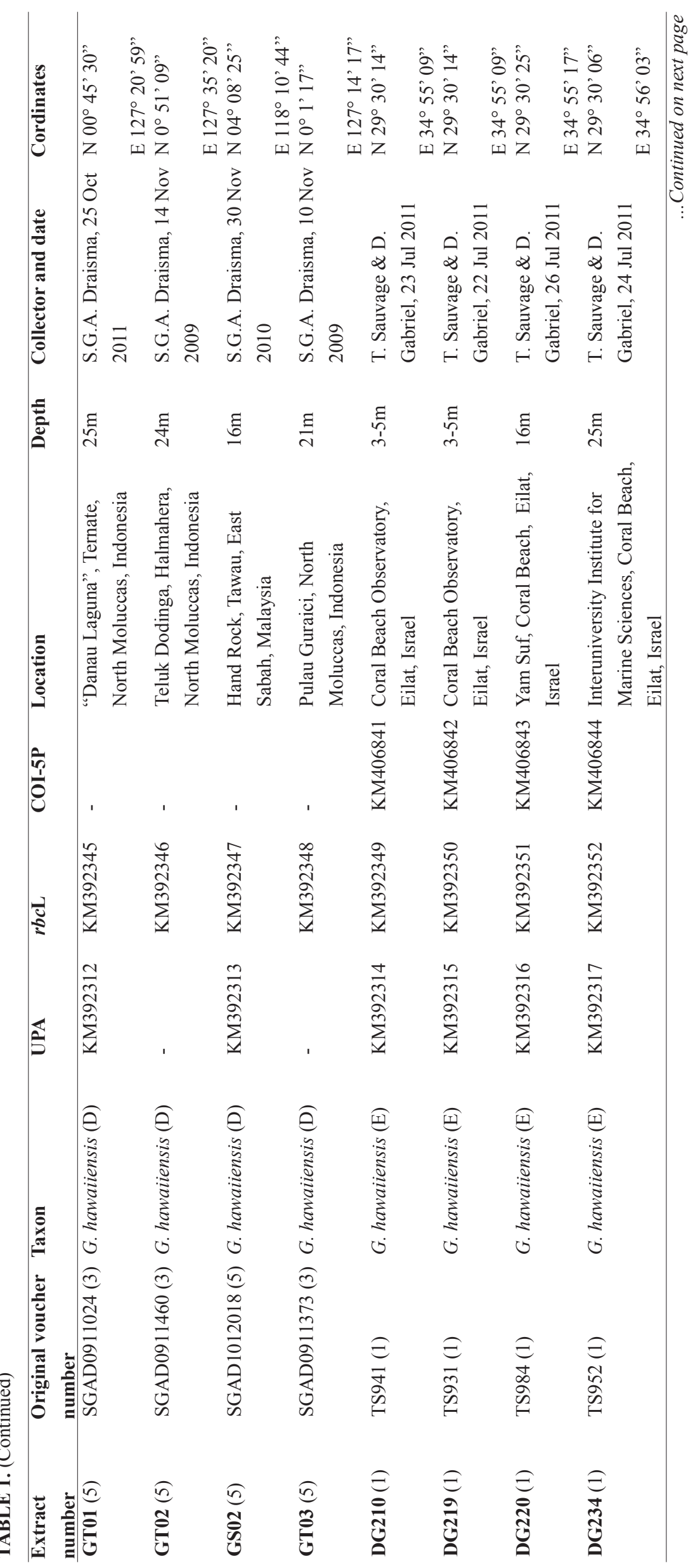




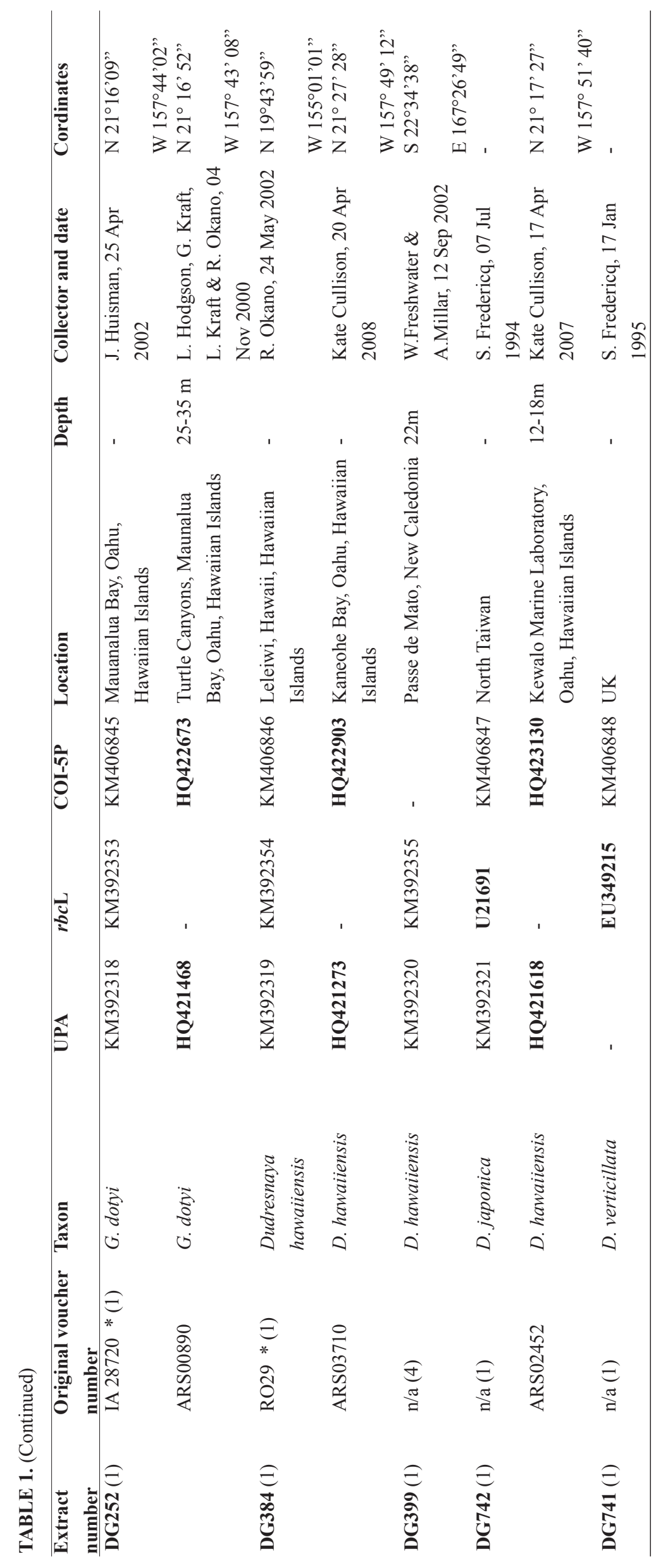


DNA extraction and PCR protocols. Total DNA was extracted from tissue dried in silica gel or stored in $96 \%$ ethanol using the QIAGEN DNeasy Plant Mini Kit (Hilden, Germany). DNA was also extracted from specimens dried onto herbarium paper using a modified extraction protocol described by Hughey et al. (2001). Three unlinked loci were amplified: chloroplast encoded UPA (plastid LSU (23S) domain V, $377 \mathrm{bp}$ ) and $r b c \mathrm{~L}$ (ribulose-1,5bisphosphate carboxylase/oxygenase large subunit, 1,467 bp), and mitochondrial encoded COI-5P (cytochrome c oxidase subunit 1, 5'-prime end, DNA barcode region, $664 \mathrm{bp}$ ). Protocols for UPA amplification followed Sherwood and Presting (2007). RbcL fragments were amplified with the primer F645 (Lin et al. 2001) and three newly designed primers, F15 5'-GTAATHCCNTAHGCNAAAATGGG-3', R916 5'-CCWGCCATDCKCATCCA-3' and R1389 5'GTTGSAGTYTCNACRAARTCAGC-3'. The combinations F15-R916 and F645-R1389 showed great universality for Rhodophyta as well as high amplification and sequencing success. Sequences of COI-5P were amplified using combinations of the primers GazF1 and GazR1 (Saunders 2005), R686 (Sherwood et al. 2010), and new primers designed for the Dumontiaceae, cox59F 5'-TTTAGGTGGTTGTATGTC-3', cox176F 5'-GATTTTTTTCATGGTTATGCC-3' and cox606R 5'-CATAGTTATWGCACCTGCC-3'. PCR products were cleaned with ExoSAP-it (Affymetrix, USB, Cleveland, Ohio, USA) and sequenced using the same set of PCR primers on an ABI 3130xl automated sequencer (Applied Biosystems, Foster, CA, USA). All new sequences are deposited in GenBank (Table 1).

Multi-gene alignment and phylogenetic analysis. Sequences were aligned manually in MacClade 4.08a (Maddison and Maddison 2005) and were unambiguous. Phylogenetic datasets were constructed for each marker individually and for all markers concatenated, being gaps considered as missing data. The model for phylogenetic analysis was determined using PartitionFinder v1.1.1 (Lanfear et al. 2012). The non-protein coding ribosomal DNA UPA was treated as a whole and the two protein coding genes, $r b c \mathrm{~L}$ and COI-5P, were divided into the three codon positions. All possible groupings of partitions were tested. On the basis of the corrected Akaike information criterion, the partition chosen was a six-part partition based on codon position in $r b c \mathrm{~L}(1)(2)(3)$ and COI-5P (4)(5)(6), with UPA included in the same partition as second codon position of COI-5P (5). The models determined for each partition were: (1) $\mathrm{GTR}+\mathrm{G}$, (2) $\mathrm{GTR}+\mathrm{I}+\mathrm{G}$, (3) $\mathrm{GTR}+\mathrm{I}+\mathrm{G}$, (4) $\mathrm{GTR}+\mathrm{I}+\mathrm{G}$, (5) $\mathrm{GTR}+\mathrm{G}$ and (6) $\mathrm{GTR}+\mathrm{I}+\mathrm{G}$.

The partitioned dataset was analyzed using maximum likelihood (ML) and Bayesian inference (BI) methods. The ML analysis was performed using RAXML v 7.2.8 (Stamatakis, 2006) using the model GTR $+\mathrm{I}+\mathrm{G}$ with 1000 searches with a random starting tree and the default, rapid hill-climbing algorithm. Nodal support values were determined using nonparametric bootstrapping with 1000 replicates. A BI Analysis was implemented in Mr Bayes v3.1.2 (Ronquist \& Huelsenbeck 2003) with default priors and the models of evolution previously specified. Markov Chain Monte Carlo searches consisted of two independent runs of four chains with three heated chains and one cold chain for 10,000,000 generations, sampled every 100 generations. Likelihood values were plotted against generation number to determine the burn-in (5,000 trees), and a majority rule consensus tree of the remaining trees was then obtained.

Barcoding gap values were calculated by dividing the minimum interspecific sequence divergence by the maximum intraspecific sequence divergence (Freshwater et al. 2010). Intraspecific values of zero were replaced by a value corresponding to a single nucleotide change, i.e., 0.27 (1 in 368 bp) for UPA and 0.15 (1 in 665 bp) for COI-5P.

\section{Results}

The complete sequence matrix (Table 1) contained 34 newly sequenced samples of G. hawaiiensis, 1 of $G$. dotyi and 2 of Dudresnaya P. L. Crouan \& H. M. Crouan 1835, representing a total of 83 new sequences (32 UPA, $34 r b c$ L, 17 COI-5P). Ten additional sequences ( 2 of G. hawaiiensis, 2 of $G$. dotyi and 6 of Dudresnaya) were retrieved from GenBank and also included in the dataset (5 UPA, $2 r b c \mathrm{~L}, 3 \mathrm{COI}-5 \mathrm{P}$ ). The final concatenated alignment consisted of 93 sequences. Species of Dudresnaya (Dudresnaya hawaiiensis R.K.S.Lee 1963: 315, Dudresnaya japonica Okamura 1902: 92 and Dudresnaya verticillata (Withering) Le Jolis 1863: 117) were chosen as the outgroup following Sherwood et al. (2010).

Although it was not possible to sequence all three molecular markers for all individuals, representatives of each clade were observed in the individual gene phylogenies (Electronic Supplementary Material, Fig. S1-S3). When analyzed separately, the different loci resulted in very similar tree topologies with ML and BI.

The multilocus analyses revealed unexpected high genetic diversity among samples of $G$. hawaiiensis. Tree topologies were similar among phylogenetic reconstructions, forming a well-supported monophyletic clade with two major monophyletic groups, each encompassing multiple lineages (Fig. 3). One group contained a lineage from the type locality (lineage A), the Hawaiian Islands, a lineage from the Central Indo-Pacific and Polynesia (lineage B), 
and a third from the Western Indian Ocean (lineage C). The second group contained a lineage from the Indo-Malayan region (lineage D) and another from the Red Sea (lineage E). Posterior-probabilities values from BI analysis for each of the lineages A-E was 0.89 or higher, except for the poorly sampled Western Indian Ocean lineage (BI $\mathrm{PP}=0.60)$. ML bootstrap values were also moderate (above 70) for most branches, failing to resolve the relation between lineages B and $\mathrm{C}$, and within lineage C. From the five lineages identified in G. hawaiiensis, lineages from isolated regions such as Hawaii and the Red Sea exhibited lower genetic diversity while lineages from the Western Indian Ocean and the Coral Triangle presented greater variability. In the Indo-Malay region, lineages B and D, each from a different major genetic group, overlapped in their distribution.

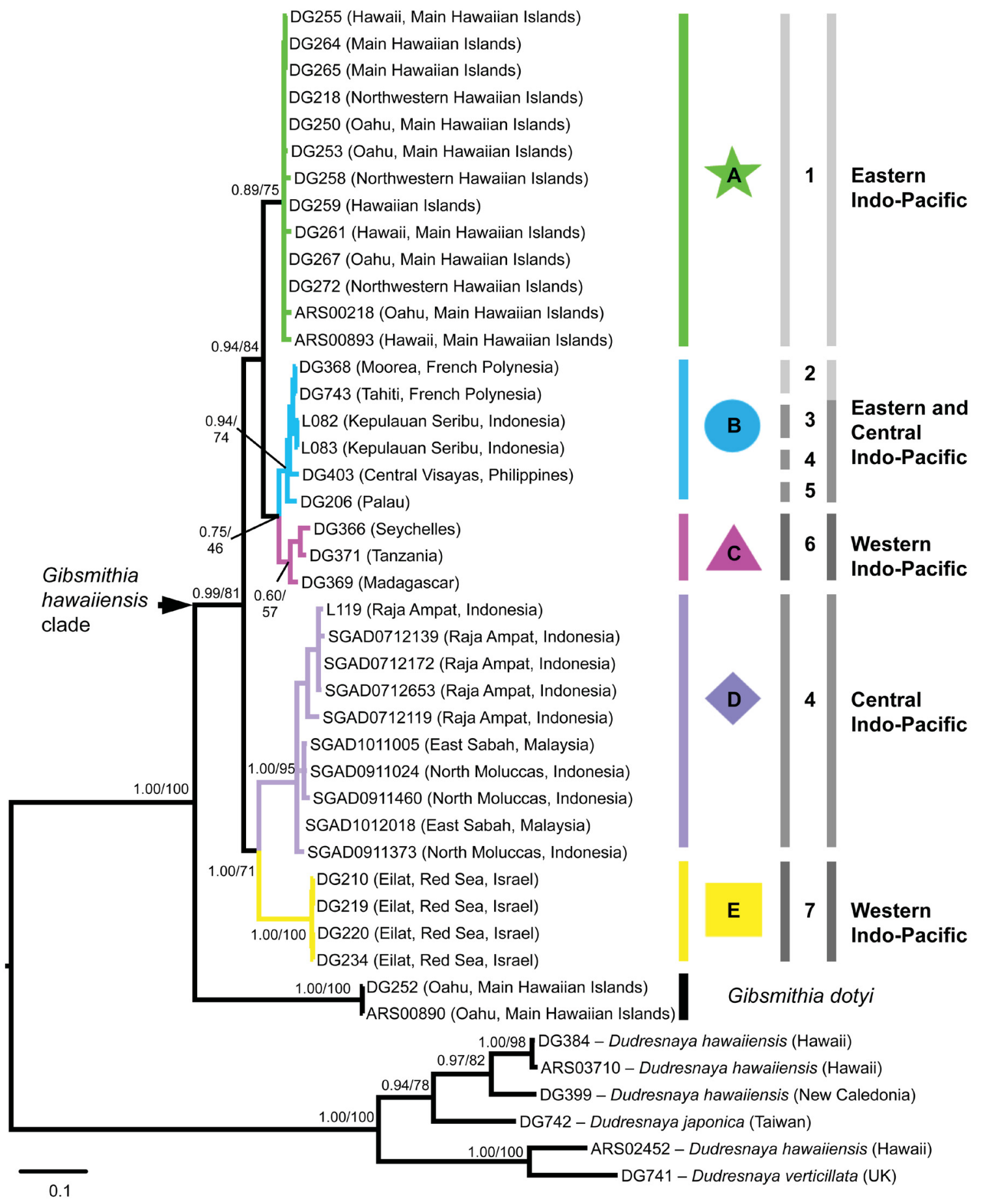

FIGURE 3. Consensus phylogram obtained from the Bayesian Inference analysis of the concatenated dataset ( $r b c \mathrm{~L}$, UPA and COI$5 \mathrm{P}$ ). Numbers besides nodes indicate posterior-probabilities (BI) and bootstrap values (ML), respectively. Scale bar indicates number of substitutions per site. A to E represent the different lineages observed. Numbers represents the respective marine provinces: 1) Hawaii; 2) Southeast Polynesia; 3) Sunda Shelf; 4) Western Coral Triangle; 5) Tropical Northwestern Pacific; 6) Western Indian Ocean; 7) Red Sea and Gulf of Aden. 
Uncorrected pairwise distance within lineages of $G$. hawaiiensis ranged from 0.0 to $0.5 \%$ for UPA (Table S1), 0.0 to $1.1 \%$ for $r b c \mathrm{~L}$ (Table S2), and 0.0 to $2.6 \%$ for COI-5P (Table S3). Distance between lineages ranged from 0.3 to $2.2 \%$ for UPA, 0.8 to $4.1 \%$ for $r b c \mathrm{~L}$, and 3.2 to $9.0 \%$ for COI-5P. Similar values have been reported for UPA (e.g., Clarkston \& Saunders 2012), rbcL (e.g., Gabriel et al. 2009), and COI-5P (e. g., Le Gall \& Saunders 2010) between species of other red algal genera. The exception observed for COI-5P, with genetic divergences within lineage B above $0.75 \%$, has also been reported for other taxonomic groups (e.g., 2.86\% for Callophyllis edentata Kylin 1925: 34 (Clarkston \& Saunders 2013). Although genetic distances between G. hawaiiensis lineages were higher than the values used to separate species, those distances were lower than the divergence values between those lineages and G. dotyi: 1.6 to $2.4 \%$ for UPA, 3.9 to $7.3 \%$ for $r b c \mathrm{~L}$ and 9.7 to $11.6 \%$ for COI-5P. The minimum between-lineage divergence was always greater than the maximum within-lineage divergence for all markers, and is here presented as a barcoding gap (Freshwater et al. 2010). The calculated gap ranged from 1.0x to 7.0x for UPA, 1.55x to $6.67 \mathrm{x}$ for $r b c \mathrm{~L}$, and $1.23 \mathrm{x}$ to $60 \mathrm{x}$ for COI-5P (Tables S1-S3). The genealogical concordance between multiple unlinked loci (Fig. 3) and the high genetic distances separating the lineages indicated that $G$. hawaiiensis is a complex of five cryptic species, following the definition of Bickford et al. (2007), i.e. species that have been classified as a single nominal species for being 'at least superficially morphologically indistinguishable'.

Differences in external morphology such as frond color, shape, size or branching were linked to the environmental conditions under which the specimen was found (Figs 1, 4-5), and did not correspond to differences between genetic lineages. Examples of this phenotypic response to environmental conditions are: long lobes with pink extremities when shaded under a coral wall (Fig. 1A, 1D, 4C); dark pink fronds with short branches when inserted between coral tips (Figs 1B, 4B); translucent fronds with long "hairs" when attached to coral surface (Figs 1C, 1E, 4A); small fronds with globular lobes when attached to dead coral fragments partially buried in the sand (Figs $1 \mathrm{~F}-\mathrm{H})$. The size, branching and number of growth rings on the stalk was independent of the frond variation and is most likely to be age related, since the stalk is perennial.

After an extensive histological study, the only lineage for which all reproductive phases were observed was the one from the Red Sea. Therefore, based on a complete suite of evidences (genetic, morphological and reproductive data), this lineage is elevated to species rank and here described as G. eilatensis sp. nov. Further sampling is required for a conclusive assessment of anatomical and reproductive features to characterize the other genetic lineages within the G. hawaiiensis complex.

\section{Taxonomy}

\section{Gibsmithia hawaiiensis Doty}

Figure 4

TYPE LOCALITY: Honolulu, Oahu, Hawaiian Islands

GEOGRAPHIC DISTRIBUTION: The Hawaiian Islands. Based on the present study, G. hawaiiensis presents a much narrower distribution range than previously thought, being restricted to the type location. Records of the species from outside the Hawaiian Islands await further study.

NOTE: The species has been described and illustrated in detail by Doty (1963). Descriptions from Abbott (1999) and Kraft (1986) are based on various samples besides the Hawaiian specimens and thus should be reconsidered. Illustrated here is a range of habits from the Main Hawaiian Islands (Hawaii, Figs. 5A-B, and Oahu, Figs. 5C-D) and the Northwestern Hawaiian Islands (Figs. 5E-F).

REPRESENTATIVE SEQUENCES: KM406832 (COI-5P), KM392323 ( $r b c \mathrm{~L})$ and KM392291 (UPA).

\section{Gibsmithia eilatensis Gabriel and Fredericq, sp. nov.}

Figures 1A, 4, 6-8

HOLOTYPE:- ISRAEL. Red Sea: Eilat, Coral Beach, N 29³0’06” E 34 56’03”, 25 m depth, 24 July 2011, DG234, female gametophyte.

Figs. 1A, 4C, 6A, T. Sauvage and D. Gabriel, deposited in LAF.

ISOTYPE:- ISRAEL. Red Sea: Eilat, Coral Beach, N 2930' 14” E 345 55'09”, 5 m depth, 22 July 2011, DG219, tetrasporophyte. Fig.

4A, T. Sauvage and D. Gabriel, deposited in LAF.

ETYMOLOGY: The specific epithet refers to the type locality in the Red Sea. 
MATERIAL EXAMINED:-ISRAEL. Red Sea: Eilat, Coral Beach, DG219 (tetrasporophyte); DG210 (female gametophyte); DG234 (female gametophyte); DG220 (male gametophyte). All specimens are deposited at LAF.

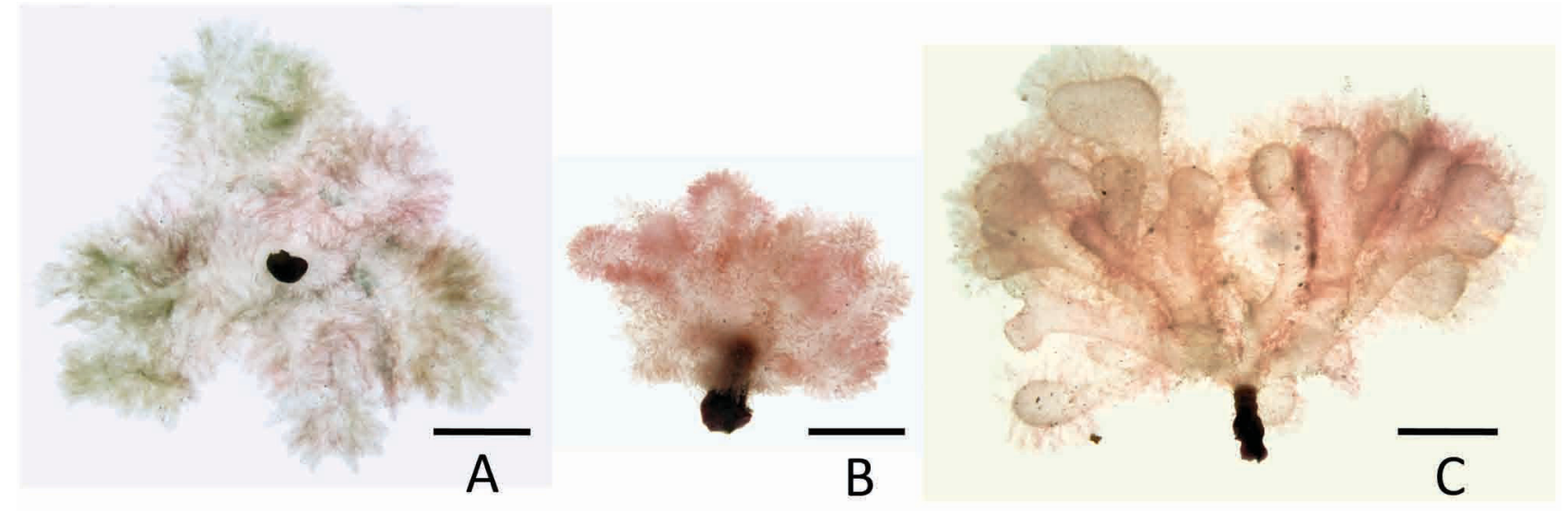

FIGURE 4. In vivo habits of G. eilatensis sp. nov. Specimens growing: A) attached to coral reef surface (DG219; isotype), B) between coral heads (DG210) and C) under a coral wall (DG234; holotype). Scale bar $=1.0 \mathrm{~cm}$
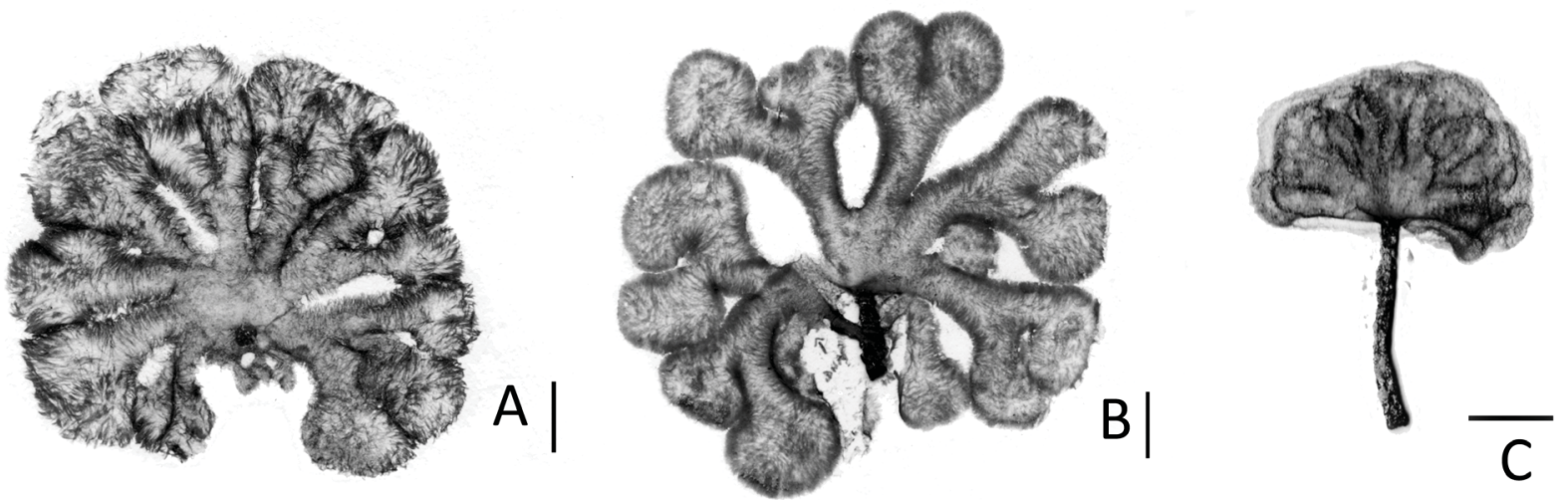

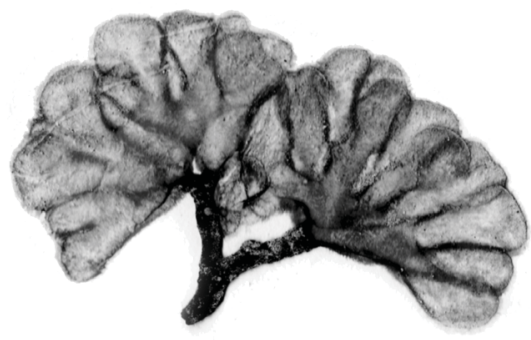

$\mathrm{D}$

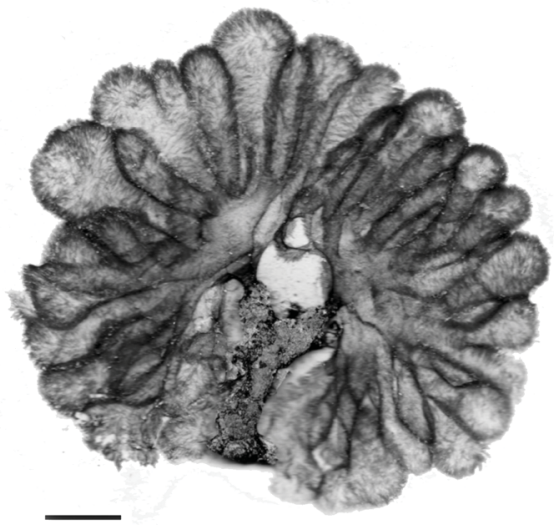

$\mathrm{E}$

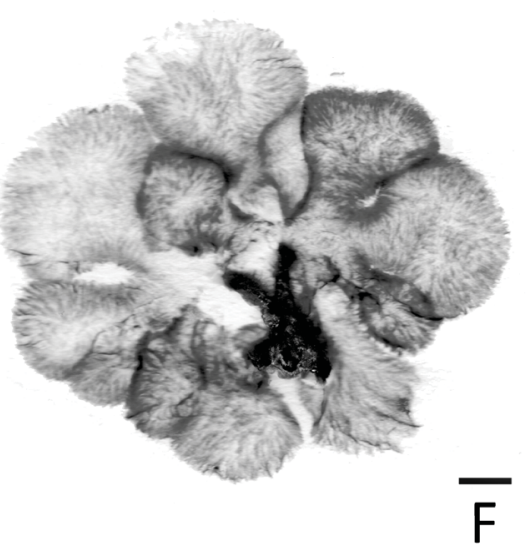

FIGURES 5. Range of habits of Gibsmithia hawaiiensis from the Hawaiian Islands (dry herbarium specimens). Main Hawaiian Islands: A) DG261, Hawaii; B) DG255, Hawaii; C) DG253, Oahu; D) DG267, Oahu. Northwestern Hawaiian Islands: E) DG258; F) DG218. Scale bar $=1.0 \mathrm{~cm}$.

ECOLOGY: Plants growing individually, subtidally to $25 \mathrm{~m}$ depth, usually in cavities of coral colonies in reef environments. $G$. eilatensis was the only species of gelatinous red algae observed in the area during the collection period (mid-June to late July). Signs of herbivory or senescence were observed in specimen DG219.

GEOGRAPHIC DISTRIBUTION: G. eilatensis was collected all along the shores of Eilat in the Gulf of Aqaba (Red Sea) and its occurrence outside this area is unknown. 


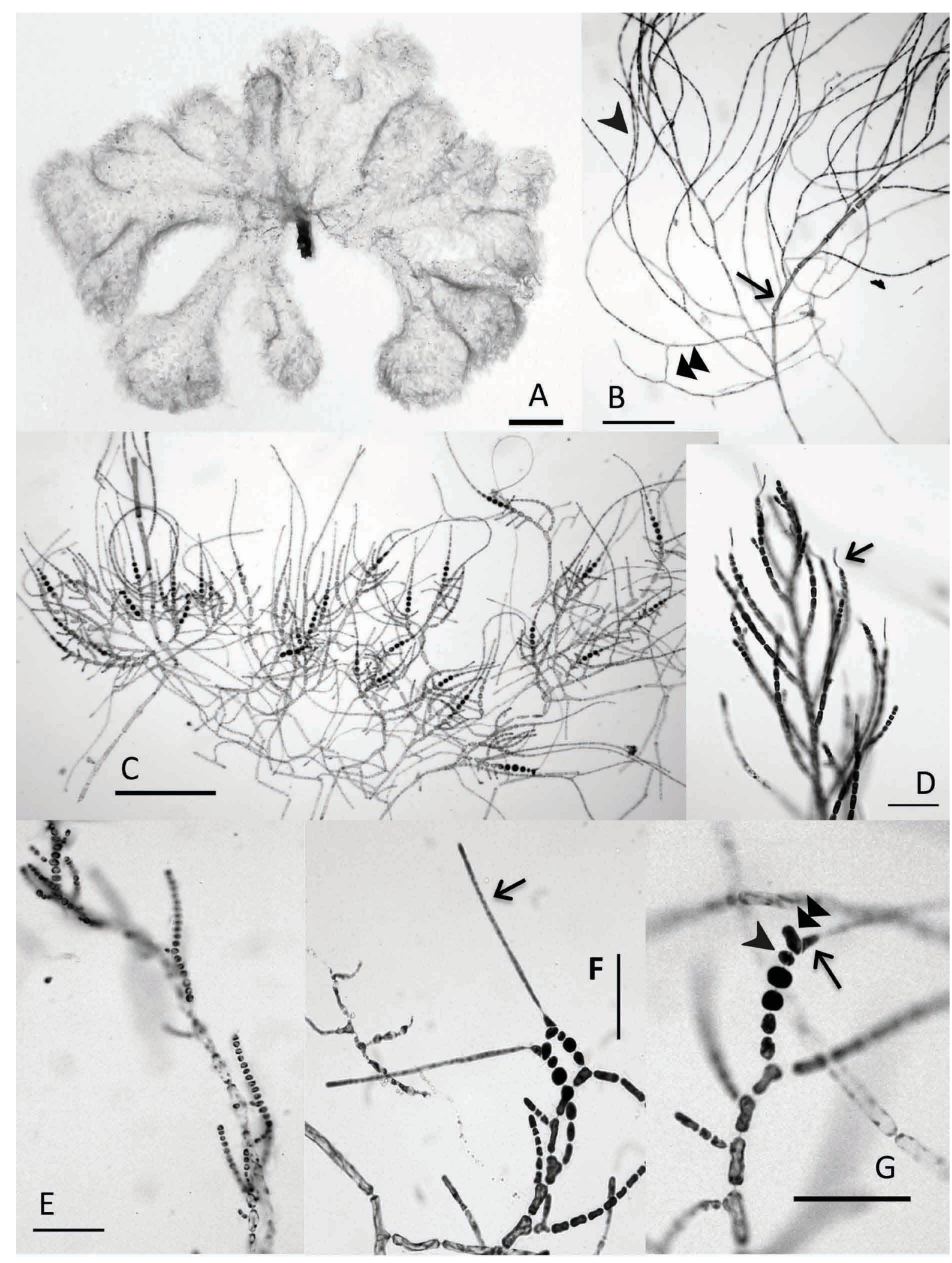

FIGURE 6. Gibsmithia eilatensis sp. nov. A) Holotype, female gametophyte, DG234, Eilat, Israel. B) Assimilatory filaments comprised of main percurrent filaments (arrow), cortical filaments (arrowhead) and rhizoidal filaments (double arrowhead). Rhizoidal filaments with cells connected to neighboring rhizoidal cells. Slide DG219-2. Scale bar $200 \mu \mathrm{m}$. C) Female pre-fertilization stages among elongated, narrow assimilatory filaments. Slide DG234-3. Scale bar $200 \mu \mathrm{m}$. D) Hairlike extensions from apical cortical cells. Slide DG210-2. Scale bar $50 \mu \mathrm{m}$. E) Branched and unbranched "seirospore" filaments. Slide DG210-5. Scale bar $50 \mu \mathrm{m}$. F) Carpogonial branch laterally positioned on assimilatory filaments, with straight and obliquely (arrow) directed trichogynes. Slide DG210-1. Scale bar 50 $\mu \mathrm{m}$. G) Carpogonial branch with laterally extended hypogynous cell (double arrowhead), small subhypogynous cell (arrowhead) and conical carpogonium (arrow) with straight trichogyne. Slide DG210-4. Scale bar $50 \mu \mathrm{m}$. 


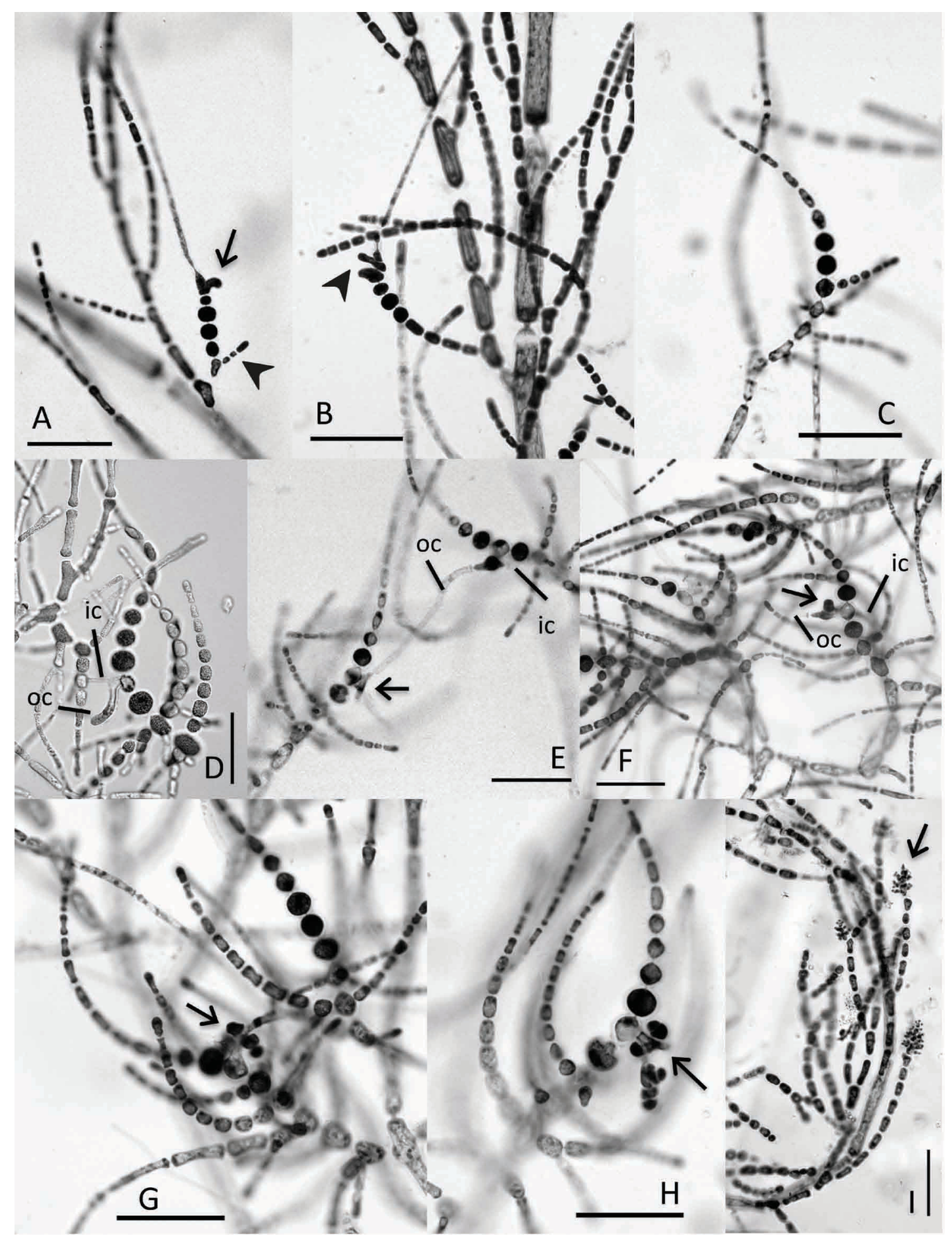

FIGURE 7. Gibsmithia eilatensis sp. nov. Early post-fertilization stages. A) Vegetative lateral branch (arrowhead) on basal cell of carpogonial filament, and curved hypogynous cell (arrow). Slide DG210-4. Scale bar $50 \mu \mathrm{m}$. B) Presumed early fertilization stage showing lateral extension of carpogonium and hypogynous cell (arrowhead). Slide DG210-1. Scale bar $50 \mu$ m. C) Auxiliary cell branch. Slide DG234-4. Scale bar $50 \mu \mathrm{m}$. D) Unsegmented incoming connecting filament (ic) partly and laterally fused to auxiliary cell, and unseptated outgoing connecting filament (oc). Slide DG234-2. Scale bar $100 \mu \mathrm{m}$. E) Incoming connecting filament (ic) segment partly fused with auxiliary cell, and outgoing connecting filament (oc) segment (arrow) partly fused with nearby auxiliary cell. Slide DG2343. Scale bar $50 \mu \mathrm{m}$. F) Gonimoblast initial (arrow) developed from the short segment partly fused to auxiliary cell, between incoming connecting filament (ic) and outgoing connecting filament (oc). Slide DG234-3. Scale bar $50 \mu \mathrm{m}$. G-H) Multiple gonimoblast initials cut off bilaterally from connecting filament segment (arrow) fused to auxiliary cell. G) Slide DG234-3. Scale bar 50 $\mu$ m. H) Slide DG234-5. Scale bar $50 \mu \mathrm{m}$. I) Young clusters of spermatangia (arrow) formed terminally and laterally in assimilatory filaments. Slide DG220-1. Scale bar $50 \mu \mathrm{m}$. 
DESCRIPTION: Thalli of furry gelatinous clusters of unbranched to pseudodichotomously branched blush, pink to white lobes, with unbranched cartilaginous stalk, and round, dark to light pink holdfast. Medullary filaments abundant, colorless, of elongate cells subtending assimilatory filaments comprised of main percurrent filaments and straight cortical filaments comprised of 20-35 rectilinear to semispherical cells, sparingly branched laterals, and thin rhizoidal filaments growing thallus inwards, intertwined with medullary filaments. Seirospore filaments present. Plants dioecious, with isomorphic tetrasporophytes. Carpogonial branches borne along the middle portion of cortical filaments, straight, 5-(8-10)-15 cells long, with the terminal 5-7 cells modified; basal cells of carpogonial branches occasionally bearing short unbranched vegetative laterals; conical carpogonium cut off by oblique division, offcentered on large hypogynous cell; subhypogynous cell smaller and rounder than the cells flanking it; trichogyne straight, elongate; hypogynous cell in functional carpogonial branches extend laterally, producing a bulge. Auxiliary cell branch 13-(19-20)-24 cells long, with 3-(5)-7 modified cells, rounder than surrounding cells, darkly staining; basal 3-10 cells with unbranched filaments surrounding carposporangia; 4-12 terminal cells rectilinear, decreasing in size towards apex. Connecting filaments septate, often diploidizing multiple auxiliary cells $(>5)$ nearby. Gonimoblast initials cut off from bulge at junction of outgoing connecting filament with auxiliary cell. Spermatangia borne radially on 3-(5)-6 terminal cortical cells, forming corncob-like structures; spermatangial heads borne in a similar position of tetrasporangia. Tetrasporangia sessile, isolated, usually borne on the adaxial side of percurrent filaments, terminal or lateral on short lateral branches, in patches along the upper part of gelatinous branches, 10-20 cells below the surface; tetrasporangia decussately to cruciately divided.

Habit and vegetative morphology. Thalli consist of furry, gelatinous clusters of unbranched to pseudodichotomously branched lobes (Fig. 6) that are predominantly blush in color (Fig. 4), occasionally pink to whitish (Fig. 1A). Exserted cortical filaments from the lobes' surface are prominently visible underwater (Fig. 1A). The unbranched cartilaginous stalk (Figs 4, 6A) is attached to the substratum by a round, dark to light pink holdfast. Cortical filaments are cut off alternately and sparingly from widely divergent main assimilatory filaments referred to as percurrent filaments and consist of rectilinear to spherical cells decreasing in size towards the surface $(5-166.25) \times(3.75-11.25) \mu \mathrm{m}$ (Figs 6B-C). Abundant colorless medullary cells are elongated and transition into distal assimilatory percurrent filaments (Fig. 6C) whose cells measure 36.25-300 $\times 3.75-11.25 \mu \mathrm{m}$. Cells of lower cortical filaments cut off narrow rhizoidal filaments that connect to nearby rhizoidal cells (Fig. 6B). Hair-like structures (6D) of variable length (12.5-120) $\times$ $1.25 \mu \mathrm{m}$ occasionally extend from the apical cells of cortical filaments and staining darkly with aniline blue when short and become almost colorless when long. Rhizoidal filaments cut off from lower cortical cells grow thallus inward where they become intertwined with medullary filaments. Straight, small-celled, scarcely branched and unbranched seirospore filaments are present (Fig. 6E) in tetrasporophytes.

Reproductive morphology. Thalli are dioecious, with isomorphic tetrasporophytes. Female pre-fertilization stages are scattered among elongated, narrow assimilatory filaments (Fig. 6C). Carpogonial branches are formed laterally on assimilatory filaments, replacing normal vegetative filaments (Figs 6F-G) in which the 5-9 upper cells transform into spherical cells while the subtending lower cells remain narrow and elliptic like other vegetative cells (Figs 6F-6G). Transformed cells of the carpogonial filaments remain unbranched while the basal and lowermost untransformed cells may cut off short unbranched lateral cell strands growing distally and obliquely (Figs 7A-B). The unfertilized carpogonium is conical with a long, straight trichogyne (Figs 6F-G, 7A-B), separated by an oblique division from the hypogynous cell. The hypogynous cell extends laterally and obliquely (Figs $6 \mathrm{~F}-\mathrm{G}$ ). The subelliptical subhypogynous cell is very small (Figs 6F-G, 7A), with the cell subtending it the largest cell of the carpogonial branch. Auxiliary cell filaments (Fig. 7C) are homologous in position and origin to the carpogonial branches and cortical filaments. Three to seven transformed intercalary cells of an auxiliary cell filaments (Figs 7C-E) become darkly staining, enlarged and roundish, and flank below and above an auxiliary cell that remains small, cytoplasm-poor and colorless (Figs 7D-F). Some of these dark cells or untransformed cells below bear unbranched laterals growing distally and obliquely (Fig. 7C). After presumed fertilization, the carpogonium produces a lateral extension that follows the orientation of the expanding hypogynous cell (Figs 7A-7B). Upon reaching an auxiliary cell, an unsegmented, hyaline incoming connecting filament connects laterally to the upper side of the auxiliary cell (Fig. 7D). It is assumed that during this process a product of the fertilization nucleus is transferred from the connecting filament to the auxiliary cell. Following this diploidization of an auxiliary cell, the incoming connecting filament continues to grow as an outgoing connecting filament (Fig. 7D). When reaching another auxiliary cell, the former outgoing filament acts as a new incoming filament, developing cross walls at the site of a new diploidization (Fig. 7E) that leads to the formation of a short segment that partly fuses with the auxiliary cell and then continues as an outgoing connecting filament (Fig. 7E). A single roundish gonimoblast initial (Figs 7E-F) is cut off from the short segment formed on the point of contact between the auxiliary cell and the connecting filament. The outgoing connecting filament continues to reach nearby auxiliary cells and before 
reaching a new auxiliary cell develops a cross wall, forms a short segment that contains part of the divided fertilization nucleus which fuses with the auxiliary cell (Figs 7E-F). Following the formation of the first gonimoblast initial, the fertilization nucleus in the generative segment cuts off additional gonimoblast cells that each will continue to divide laterally and radially resulting in small clusters of cells (Figs 7G-H). The issuing of a connecting filament primordium from the carpogonium was only observed once (Fig. 7B), prior to its fusion with the hypogynous cell and cells below the subhypogynous cell. Mature auxiliary cell branches are 13-(19-20)-24 cells long (Figs 7C-H). The lowermost 3-10 cells of the auxiliary cell filament typically cut off short-celled unbranched vegetative filaments that surround the gonimoblast cells $(7 \mathrm{G}-\mathrm{H})$ as they mature into carposporangia. The upper 4-12 terminal cells of the auxiliary cell filament are rectilinear, decreasing in size toward the apex (Figs 7C, 7E, 7H). Gonimoblast cells resulting from a single diploidization event mature gradually in a synchronized fashion, resulting in same-sized cells (Fig. 7H). Mature carposporophytes were not observed.

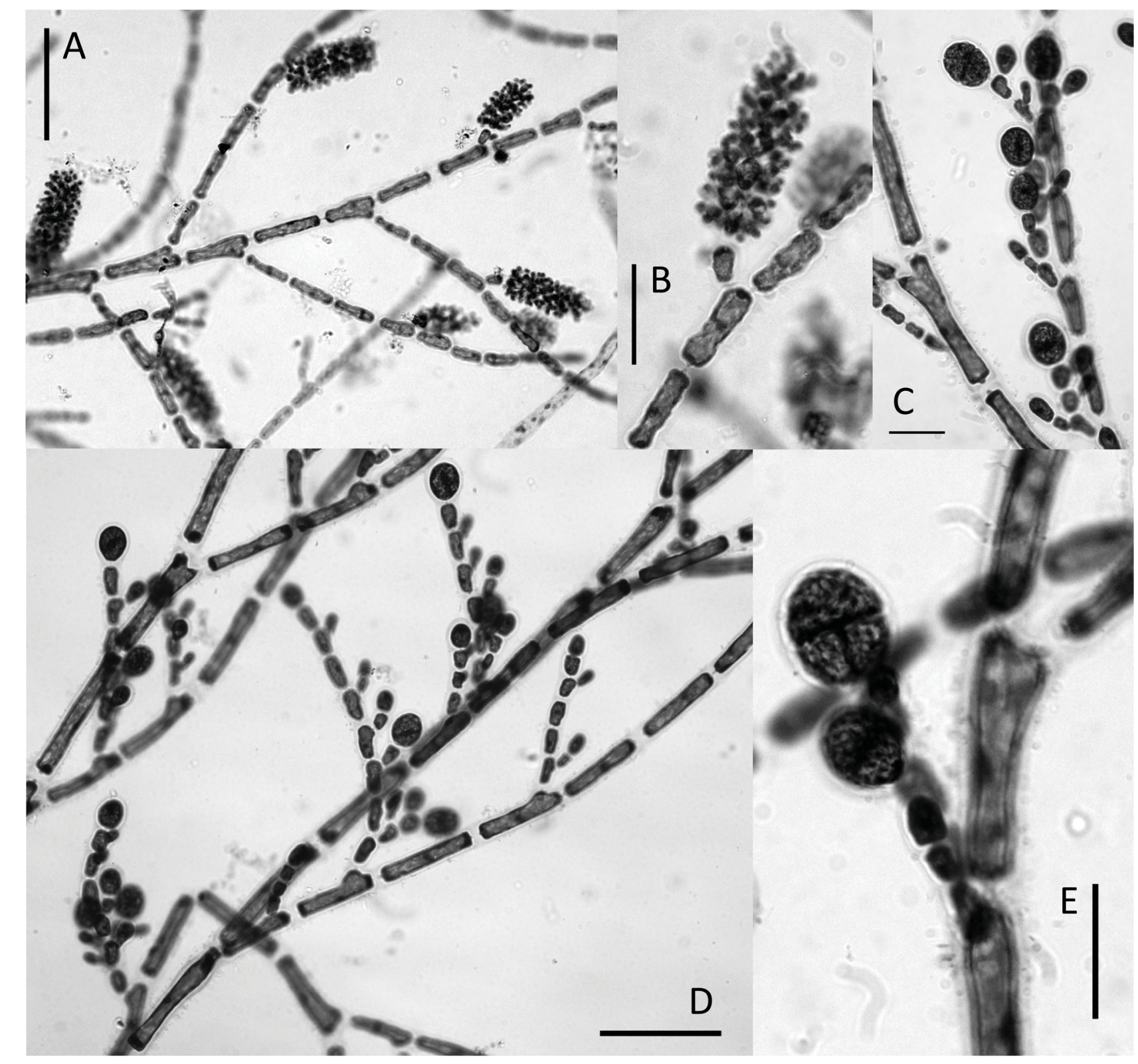

FIGURE 8. Gibsmithia eilatensis sp. nov. A-B) Mature corncob-like spermatangial heads. A) Slide DG220-1. Scale bar 50 $\mu$ m. B) Slide DG220-1, scale bar $20 \mu \mathrm{m}$. C) Young and mature tetrasporangia. Slide DG219-1. Scale bar $20 \mu \mathrm{m}$. D-E) Terminal and lateral tetrasporangial initials growing on lateral assimilatory filaments, and decussate and cruciate tetrasporangia. D) Slide DG219-1. Scale bar $50 \mu \mathrm{m}$. E) Slide DG219-1. Scale bar $20 \mu \mathrm{m}$.

Young clusters of spermatangia are formed on terminal and lateral cells of assimilatory cortical filaments on dioecious gametophytes (Fig. 7I). The spermatangial initials are cut off radially as multiple small protrusions on 3-(5)-6 consecutive cells in a single filament. When the lateral cell filament is 7 cells long, the 6-celled spermatangial 
branch is pedicellate (Figs 8A-B); if 6 cells long the corncob-like structure is sessile, and if more than 6 cells long, the male reproductive structure is terminally positioned on a lateral branch (Fig. 7I). Mature spermatangial heads, $25-(50-81.25) \times 11.25(15-18.75) \mu \mathrm{m}$ (Figs 8A-B), are oblong and borne in a similar position as the tetrasporangia on cortical filaments. Spermatangia are abundant, measuring $(2-2.5) \times(1.5-2) \mu \mathrm{m}$ (Fig. 8B).

Tetrasporangial initials (Figs 8C-D) are cut off unilaterally in short series either obliquely from the upper side of cells on short laterals on cortical filaments, or are terminal on these short laterals in the upper part of the gelatinous branches. Tetrasporangia are usually decussately divided (Fig. 8E), sometimes cruciate (Fig. 8C), (15-18.75) × (11.2513.75) $\mu \mathrm{m}$.

NOTE: The present description was based on a small number of samples found after extensive searches along the coast of Eilat. Although all three life history phases were observed for G. eilatensis, connecting filament formation and mature cystocarps were not observed in our extensive squash preparations. Unlike those of G. hawaiiensis, cortical filaments in G. eilatensis are rarely cut off oppositely from the main percurrent filaments and are usually unbranched or sparingly alternately branched (Table 2). Seirospores are found in chains as in G. hawaiiensis, but occasionally present short branchlets. Carpogonial branches bear an enlarged hypogynous cell and a very small subhypogynous cell, while all cells of the carpogonial branch are similar in size and shape in G. hawaiiensis. Auxiliary cell branches are also composed of similarly shaped modified cells in G. hawaiiensis, while auxiliary cell is smaller in G. eilatensis. The origin of the gonimoblast initials is from the point of junction between the connecting filament and the auxiliary cell, contrasting with the generitype, where gonimoblasts are initiated from the auxiliary cell. Tetrasporangia are mostly borne on short lateral branches on inner cells of cortical filaments, while in G. hawaiiensis they have a 2-3-celled pedicel.

REPRESENTATIVE SEQUENCES: KM406844 (COI-5P), KM392352 (rbcL) and KM392317 (UPA).

TABLE 2. Anatomical comparison between Gibsmithia eilatensis sp. nov. and G. hawaiiensis Doty 1963. Based on observations from Doty (1963) and the present study.

\begin{tabular}{|c|c|c|}
\hline Feature & G. hawaiiensis Doty 1963 & G. eilatensis sp. nov. \\
\hline Cortex & $\begin{array}{l}\text { Main percurrent filaments oppositely or radially } \\
\text { bearing pseudodichotomously branched cortical } \\
\text { filaments }\end{array}$ & $\begin{array}{l}\text { Main percurrent filaments alternately bearing } \\
\text { unbranched or sparingly alternately branched } \\
\text { cortical filaments }\end{array}$ \\
\hline Seirospores & Seirospores in unbranched chains & Seirospores in chains with occasional branchlets \\
\hline Carpogonial branch & $\begin{array}{l}4 \text { modified spherical cells, with subhypogynous } \\
\text { cell sometimes smaller, and carpogonium borne } \\
\text { terminally and excentrically at an angle of } 45^{\circ}\end{array}$ & $\begin{array}{l}\text { 5-9 modified spherical cells, with laterally } \\
\text { enlarged hypogynous cell, very small } \\
\text { subhypogynous cell, and carpogonium borne } \\
\text { terminally and excentrically }\end{array}$ \\
\hline Auxiliary cell branch & 4 modified spherical cells & $\begin{array}{l}\text { 3-7 modified spherical cells with auxiliary cell } \\
\text { smaller }\end{array}$ \\
\hline Carposporangia & $\begin{array}{l}\text { Gonimoblast formed from the auxiliary cell near } \\
\text { the junction with a connecting filament }\end{array}$ & $\begin{array}{l}\text { Gonimoblast formed from the short segment of a } \\
\text { connecting filament fused with the auxiliary cell }\end{array}$ \\
\hline Tetrasporangia & $\begin{array}{l}\text { Tetrasporangia are mostly decussate, rarely } \\
\text { tetrahedral or cruciate, borne laterally from inner } \\
\text { cortical cells on a } 2-3 \text {-celled pedicel }\end{array}$ & $\begin{array}{l}\text { Tetrasporangia are mostly decussate, rarely } \\
\text { cruciate, borne unilaterally or terminally on short } \\
\text { laterals on inner cortical branches. }\end{array}$ \\
\hline Confirmed distribution & Waikiki, Oahu, Hawaiian Islands & Eilat, Gulf of Aqaba, Red Sea \\
\hline
\end{tabular}

\section{Discussion}

Based on an unreported number of specimens, Karam-Kerimian (1976) suggested the existence of more than one species of Gibsmithia with exerted filaments in French Polynesia, but failed to indicate the reason for species distinctions. This suggestion was refuted by Kraft (1986) who interpreted the variability in anatomy as plastic phenotypic traits. The present data confirm that $G$. hawaiiensis is in fact a species complex, presenting high cryptic diversity as previously reported in other members of Dumontiaceae by Saunders (2008) and overall highlights the importance of molecular analyses when assessing variation within this family. 
The here newly reported and sequenced samples of the G. hawaiiensis complex extend the known distribution range of the group (Fig. 2). Latitudinally, the distribution is extended to the north by the first Gibsmithia record for the Red Sea (Fig. 1A), here described as G. eilatensis sp. nov. In addition, the occurrence of the species complex in Raja Ampat (Indonesia; Fig. 1F), Kepulauan Seribu (Indonesia; Fig. 1B), and East Sabah (Malaysia) confirms the provisional records of the alga for these areas as proposed by Atmadja and Prud'homme van Reine (2010) and Draisma (2012). The species complex is also reported for the first time for Madagascar, the North Moluccas (Indonesia; Fig. 1C) and Visayas (Philippines). Unpublished data (S.G.A. Draisma, pers. obs.) also suggest the presence of the complex in Bali, North Sulawesi (Fig. 1H), East Kalimantan, East Nusa Tenggara (Indonesia), East Johor (Fig. 1E), Pulau Labuan (Fig. 1G), West Sabah (Fig. 1D) and North Sabah (Malaysia), and Mindanao (Philippines), further extending the present distribution. Records of the species complex in other (sub)tropical locations within the Indo-Pacific are likely correct due to the alga's unmistakable appearance, but accurate assessments at the species-level will require further genetic studies.

Although the remaining three lineages of the complex await further studies for the description of each new species, we conclude that the generitype is restricted to the Hawaiian Islands, raising the number of endemic marine algal species in the archipelago to 57 out of a total of 519 species (Tsuda 2014). Besides G. eilatensis, which is restricted to the Red Sea, most of the to be described species are also endemics for subregions within the Western Indian Ocean and the Coral Triangle.

Aside from the species belonging to the Gibsmithia hawaiiensis complex, the other congenerics present an overall non-hairy appearance, and can be clearly discriminated from each other by the branching pattern of the gelatinous thallus (Kraft 1986): rosette clusters of short flattened branches in $G$. dotyi, subdichotomous long cylindrical branches in $G$. womersleyi, and very irregularly branched lobes in G. larkumii. The unique combination of gelatinous branches growing on cartilaginous stalks is common throughout the genus except in G. larkumii in which the gelatinous thalli are attached to the substratum only by cartilaginous discs (Schils \& Coppejans 2002). No anatomical variation has been previously reported in the few records of G. larkumii (Kraft 1986; Schils \& Copejans 2002; N'Yeurt \& Payri 2010) and G. womersleyi (Kraft 1986; Womersley 1994). Interestingly, 'consistent habit differences' were also reported within G. dotyi since its original description, when Kraft (1986) suggested the existence of a separate species but refrained from making the separation since diagnostic features were not consistently present in the small sample size. Genetic analyses of $G$. dotyi throughout its distribution range are needed to assess the species boundaries and may possibly uncover cryptic diversity as here reported for G. hawaiiensis.

This is the first study focusing on the molecular phylogeny of tropical members in the Dumontiaceae, since all 17 genera in the family primarily occur in cool- and cold-temperate waters, except for Gibsmithia and Dudresnaya (Kraft, 1986). The unsuspected species diversity reported in the present study suggests the existence of a larger number of taxa, and therefore the family might be underrepresented in checklists of tropical algae worldwide.

Rare and cryptic species that remain undescribed are at the greatest risk of extinction (Brodie et al. 2009). Recognizing the high genetic diversity within the G. hawaiiensis species complex highlights the unknown algal diversity still to be discovered, as emphasized by De Clerck et al. (2013). Although seaweeds are rarely subject to specific environmental protection laws, coral reefs usually are, and therefore protecting this alga's habitat enables the species to adapt to the environment as it changes (Brodie et al. 2009). Little is known about this alga's resilience to environmental fluctuations. Although the stalk is persistent, the reproductive structures grow inside the sensitive gelatinous branches (Huisman et al. 2007).

Unraveling the genetic diversity of the $G$. hawaiiensis complex and determining its distribution pattern is a first step towards understanding the evolutionary history and biogeography of these red algae. The recognition of its lineages as new species in future studies would contribute to resolving the taxonomic diversity of this complex and contribute to accurate marine biodiversity assessments to guide marine conservation strategies.

\section{Acknowledgements}

We thank Willem Prud'homme van Reine, Eric Coppejans, Olivier De Clerk, Isabella Abbott, Wilson Freshwater and other collectors listed in Table 1 for providing specimens used in the present study. DG was supported by Direcção Regional da Ciência e da Tecnologia (M3.1.9/F/013/2008) and Fundação para a Ciência e a Tecnologia (SFRH/ BPD/64963/2009). This research was funded by SYNTHESIS grant NL-TAF-4691 to DG and SD, and the National Science Foundation grants DEB-0743024 and DEB-0936216 to SF. DG and T Sauvage are thankful for the ASSEMBLE 
travel grant 227799. SD received funding, permits and logistic support from: Prince of Songkla University New Researcher Scholarship, Schure-Beijerinck-Popping Fund and TREUB Maatschappij, Naturalis Biodiversity Center (NBC), Netherlands Organization for Scientific Research (ALW-NWO grant 85200050 and WOTRO-NWO grant R 85-381), Bert W. Hoeksema (NBC); University of Malaya Research Grant RG107-11SUS, Borneo Marine Research Institute, World Wildlife Fund-Malaysia, Economic Planning Unit Sabah, Sabah Parks and Department of Fisheries Sabah; Research Centre for Oceanography of the Indonesian Institute of Sciences (PPO-LIPI), RISTEK, and Yosephine Tuti (RCO-LIPI). We also thank Bridgette Clarkston and an anonymous reviewer for providing helpful comments on the manuscript.

\section{References}

Abbott, I. (1999) Marine red algae of the Hawaiian Islands. Bishop Museum Press, Honolulu, Hawaii, 477 pp.

Atmadja, W.S. \& Prud'homme van Reine, W.F. (2010) Checklist of the Seaweed Species Biodiversity of Indonesia. Coral Reef Information and Training Centre, Jakarta, $72 \mathrm{pp}$.

Bickford, D., Lohman, D.J., Sodhi, N.S., Ng, P.K.L., Meier, R., Winker, K., Ingram, K.K. \& Das, I. (2007) Cryptic species as a window on diversity and conservation. Trends in Ecology and Evolution 22: 148-155.

http://dx.doi.org/10.1016/j.tree.2006.11.004

Brodie, J., Andersen, R.A., Kawachi, M. \& Millar, A.J.K. (2009) Endangered algal species and how to protect them. Phycologia 48: 423-438. http://dx.doi.org/10.2216/09-21.1

Clarkston, B.E. \& Saunders, G.W. (2012) An examination of the red algal genus Pugetia (Kallymeniaceae, Gigartinales), with descriptions of Salishia firma gen. \& comb. nov., Pugetia cryptica sp. nov. and Beringia wynnei sp. nov. Phycologia 51: 33-61. http://dx.doi.org/10.2216/11-01.1

Clarkston, B.E. \& Saunders, G.W. (2013) Resolving species diversity in the red algal genus Callophyllis (Kallymeniaceae, Gigartinales) in Canada using molecular assisted alpha taxonomy. European Journal of Phycology 48: 27-46. http://dx.doi.org/10.1080/09670262.2013.767943

Crouan, P.L. \& Crouan, H.M. (1835) Observations microscopique sur le genre Mesogloia Agardh. Annales des Sciences Naturelles, Botanique 9: 98-100.

De Clerck, O., Guiry, M.D., Leliaert, F., Samyn, Y. \& Verbruggen, H. (2013) Algal taxonomy: a road to nowhere? Journal of Phycology 49: 215-225.

http://dx.doi.org/10.1111/jpy.12020

Doty, M.S. (1963) Gibsmithia hawaiiensis gen. n. et sp. n. Pacific Science 17: 458-465.

Draisma, S.G.A. (2012) Macroalgae. In: Kassem, K., Hoeksema, B. \& Y.A. Affendi (Eds.) Semporna Marine Ecological Expedition. Kota Kinabalu Malaysia, pp. 77-117.

Freshwater, D.W., Tudor, K., O’Shaughnessy, K. \& Wysor, B. (2010) DNA barcoding in the red algal order Gelidiales: Comparison of COI with $r b c \mathrm{~L}$ and verification of the "barcoding gap". Cryptogamie, Algologie 31: 435-449.

Gabriel, D., Schils, T., Neto, A.I., Paramio, L. \& Fredericq, S. (2009) Predaea feldmannii subsp. azorica (Nemastomataceae, Nemastomatales), a new subspecies of red algae (Rhodophyta) from the Azores. Cryptogamie, Algologie 30: $251-271$.

Guiry, M.D. \& Guiry, G.M. (2016) AlgaeBase. World-wide electronic publication. National University of Ireland, Galway (accessed 20 May 2016)

Hughey, J.R., Silva, P.C. \& Hommersand, M.H. (2001) Solving taxonomic and nomenclatural problems in Pacific Gigartinaceae (Rhodophyta) using DNA from type material. Journal of Phycology 37: 1091-1109. http://dx.doi.org/10.1046/j.1529-8817.2001.01048.x

Huisman, J.M., Abbott, I.A. \& Smith, C.M. (2007) Hawaiian reef plants. University of Hawaii Sea Grant College Program, Honolulu, Hawaii, 264 pp.

Karam-Kerimian, T.B. (1976) Structure, reproduction et discussion sur la position systématique du genre Gibsmithia (Rhodophyceae). Bulletin du Muséum National D'Historie Naturelle, Série 3 365: 21-32.

Kraft, G. (1986) The genus Gibsmithia (Dumontiaceae, Rhodophyta) in Australia. Phycologia 25: 423-447.

http://dx.doi.org/10.2216/i0031-8884-25-4-423.1

Kylin, H. (1925) The marine red algae in the vicinity of of the Biological Station at Friday Harbor, Washington. Lunds Universitets Arsskrift, Ny Följd, Andra Afdelningen 21: 1-87.

Lanfear, R., Calcott, B., Ho, S.Y.W. \& Guindon, S. (2012) PartitionFinder: Combined selection of partitioning schemes and substitution 
models for phylogenetic analyses. Molecular Biology and Evolution 29: 1695-1701.

http://dx.doi.org/10.1093/molbev/mss020

Le Gall, L. \& Saunders, G.W. (2010) DNA barcoding is a powerful tool to uncover algal diversity: A case study of the Phyllophoraceae (Gigartinales, Rhodophyta) in the Canadian Flora. Journal of Phycology 46: 374-389.

http://dx.doi.org/10.1111/j.1529-8817.2010.00807.x

Le Jolis, A. (1863) Liste des algues marines de Cherbourg. Mémoires de la Société Impériale des Sciences Naturelles de Cherbourg 10: 5-168.

Lee, R.K.S. (1963) The structure and reproduction of Dudresnaya hawaiiensis sp. nov. (Rhodophyta). American Journal of Botany 50: 315-319.

Lin, S., Fredericq, S. \& Hommersand, M. (2001) Systematics of the Delesseriaceae (Ceramiales, Rhodophyta) based on large subunit rDNA and $r b c$ L sequences, including the Phycodryoideae, subfam. nov. Journal of Phycology 37: 881-899. http://dx.doi.org/10.1046/j.1529-8817.2001.01012.x

Maddison, W.P. \& Maddison, D.R. (2005) MacClade 4: analysis of phylogeny and character evolution. Version 4.8a. Available from: http://macclade.org (accessed 1 September 2016)

Millar, A. \& Kraft, G. (1984) The red algal genus Acrosymphyton (Dumontiaceae , Cryptonemiales) in Australia. Phycologia 23: 135145. http://dx.doi.org/10.2216/i0031-8884-23-2-135.1

N'Yeurt, A.D.R. \& Payri, C.E. (2010) Marine algal flora of French Polynesia III. Rhodophyta, with additions to the Phaeophyceae and Chlorophyta. Cryptogamie. Algologie 31: 3-196.

Okamura, K. (1902) Nippon Sorui-meii. Keigyosha, Tokyo, 276 pp.

Payo, D.A., Leliaert, F., Verbruggen, H., D’hondt, S., Calumpong, H.P. \& De Clerck, O. (2013) Extensive cryptic species diversity and fine-scale endemism in the marine red alga Portieria in the Philippines. Proceedings of the Royal Society B: Biological Sciences 280: 2012.2660 .

http://dx.doi.org/10.1098/rspb.2012.2660

Ronquist, F. \& Huelsenbeck, J.P. (2003) MrBayes 3: Bayesian phylogenetic inference under mixed models. Bioinformatics 19: 15721574 .

http://dx.doi.org/10.1093/bioinformatics/btg180

Saunders, G.W. (2005) Applying DNA barcoding to red macroalgae: a preliminary appraisal holds promise for future applications. Philosophical transactions of the Royal Society of London. Series B, Biological sciences 360: 1879-88. http://dx.doi.org/10.1098/rstb.2005.1719

Saunders, G.W. (2008) Barcode examination of the red algal family Dumontiaceae in Canadian waters reveals substantial cryptic species diversity. 1. The foliose Dilsea-Neodilsea complex. Botany 789: 773-789.

http://dx.doi.org/10.1139/B08-001

Schils, T. \& Coppejans, E. (2002) Gelatinous red algae of the Arabian Sea, including Platoma heteromorphum sp. nov. (Gigartinales, Rhodophyta). Phycologia 41: 254-267.

http://dx.doi.org/10.2216/i0031-8884-41-3-254.1

Sherwood, A.R. \& Presting, G.G. (2007) Universal primers amplify a 23S rDNA plastid marker in eukaryotic algae and cyanobacteria. Journal of Phycology 43: 605-608. http://dx.doi.org/10.1111/j.1529-8817.2007.00341.x

Sherwood, A.R., Kurihara, A., Y Conklin, K., Sauvage, T. \& Presting, G.G. (2010) The Hawaiian Rhodophyta Biodiversity Survey (20062010): a summary of principal findings. BMC Plant Biology 10: 258.

http://dx.doi.org/10.1186/1471-2229-10-258

Stamatakis, A. (2008) The RAxML 7.0.4 Manual. Ludwig-Maximilians-Universität, Munich, 25 pp.

Tsuda, R.T. (2014) Endemism of marine algae in the Hawaiian Islands. Bishop Museum Occasional Papers 115: 23-27.

Womersley, H.B.S. (1994) The marine benthic flora of southern Australia-Part IIIA-Bangiophyceae and Florideophyceae (Acrochaetiales, Nemaliales, Gelidiales, Hildenbrandiales and Gigartinales sensu lato). Australian Biological Resources Study, Canberra, 508 pp. 